\title{
ANIMASI 2 DIMENSI SEBAGAI INFOGRAFIS PENCEGAHAN VIRUS COVID 19 PADA PAUD TERPADU ALLIFA
}

\author{
Yuli Astuti, Irma Rofni Wulandari, Abdiel Alim W, Vikiyana Haris A, \\ Fawwaz Hasanu, Bibit Aries K, Rina Puji Utami
}

Fakultas Ilmu Komputer Universitas Amikom Yogyakarta yuli@amikom.ac.id.

\begin{abstract}
For eight months, this country has experienced unusual conditions due to the coronavirus pandemic or referred to as covid-19. The education world still has to run as it should be, even though it cannot be carried out maximally; therefore, the school must carry out the learning process using an online system. For online learning at the early childhood education level, intensive parental assistance is still needed. Therefore, the delivery of messages or material is done clearly and as attractive as possible so that parents can easily convey it to their children. To describe the message of a healthy lifestyle for the prevention of the Covid-19 virus, it must also be interesting and interactive so that the messages conveyed are easily accepted for children so that in this service, an infographic 2-dimensional animation video is made about preventing the covid-19 virus with the type of mp4 file so that it can be viewed via cellphones or computer. The manufacturing stage analyzes the problem, determines the solution, chooses a solution, then continues the design by storyboarding, making character designs, writing and recording, then composting and editing, and finally testing. In this video, there are still shortcomings, namely the duration of the video is still quite short, so the information conveyed is still limited.
\end{abstract}

Keywords: 2D Animation, Infographics, Covid-19 Virus, PAUD

\begin{abstract}
Abstrak
Delapan bulan negara ini mengalami kondisi yang tidak biasa karena adanya pandemic virus corona atau sering disebut covid-19. Dunia Pendidikan tetap harus berjalan sebagaimana mestinya biarpun tidak bisa dilaksanakan secaramaksimal, oleh karena itu pihak sekolah harus melakukan proses pembelajarannya menggunakan system online. Untuk pembelajaran online di jenjang Pendidikan usia dini masih butuh pendampingan orang tua secara intensive. Oleh karena itu penyampaian pesan atau materi dilakukan dengan jelas dan semenarik mungkin agar orang tua mudah untuk menyampaikan ke anak. Untuk memberikan pesan pola hidup sehat untuk pencegahan virus covid-19 juga harus menarik dan interaktif agar pesan yang disampaikan mudah diterima untuk anak sehingga pada pengabdian ini dibuatlah video animasi 2 Dimensi infografis tentang pencehagan virus covid-19 dengan jenis file mp4 sehingga bisa dilihat melalui handphone maupun computer. Tahap pembuatannya yaitu menganalisa masalah, menentukan solusi, memilih solusi, kemudian dilanjutkan perancangan dengan storyboard, pembuatan desain karakter, penulisan naskah dan recording kemudian kompositing dan editing dan terakhir adalah pengujian. Pada video ini masih ada kekurangan yaitu durasi video masih cukup pendek sehingga informasi yang disampaikan masih terbatas.
\end{abstract}

Kata kunci: Animasi 2D, Infografis, Virus Covid-19, PAUD

MARTABE : Jurnal Pengabdian Masyarakat | 215 


\section{PENDAHULUAN}

Hampir semua negara di dunia ini mengalami musibah wabah yang tentunya banyak kerugian dan menghambat semua aktifitas, salahsatunya adalah dunia Pendidikan. Pada awal Februari 2020 semua jenjang Pendidikan di Indonesia harus merubah system pembelajaran menggunakan media online atau daring. Pada jenjang Sekolah Dasar sampai jenjang perguruan tinggi mungkin tidak begitu bermasalah atas perubahan tersebut tetapi tidak bagi jenjang Taman KanakKanak ke bawah, karena guru-guru juga masih banyak yang belum menguasai teknologi informasi untuk menunjang system pembelajaran secara daring.

Menindak lanjuti peraturan menteri pendidikan dan kebudayaan republik Indonesia nomor 4 tahun 2020 tentang pelaksanaan kebijakan Pendidikan dalam masa darurat penyebaran coronavirus disease (COVID 19) bahwa semua pembelajaran sekolah dari tingkat Pendidikan usia dini sampai tingkat perguruan tinggi untuk melakukan proses belajar mengajar dari rumah secara online atau daring . Banyak keuntungan yang didapat dalama metode pembelajaran online karena siswa tetap bisa berinteraksi dengan guru dan materi bisa tersampaikan dengan media yang berbeda dari biasanya , tetapi ini dirasakan jika jenjangnya sudah sekolah dasar ke atas. Metode ini juga memiliki kekurangan salah satunya materi yang tersampaikan tidak tidak dan monoton sehingga siswa atau pendamping harus mengeksplore sendiri . Peran pendidik untuk menyampaiakan materi sangat dibutuhkan dengan memberi materi yang terlihat menarik bagi anak didik usia dini, agar dalam proses pembelajaran lebih menyenangkan .

Dalam situasi yang ada sekarang, penting sekali guru untuk selalu meyisipkan pesan tentang pola hidup sehat ke anak didik, informasiinformasi terkait penyebab adanya pembelajaran secara daring seperti tentang virus corona dan cara hidup sehat sebagai upaya untuk mencegah penularanya. Akan tetapi jika pesanpesan tersebut hanya berbentuk text yang dikirim melalui whatsapp orang tuanya maka pesan tersebut tidak akan tersampaikan dengan maksimal karena tidak akan menarik buat anak-anak dan orang tua juga belum tentu menyampaikan dengan intonasi yang baik. Sehingga perlu sekali disampaikan dalam bentuk yang lebih menarik. Hal ini sangat dibutuhkan siswa jika penyampaian informasi tersebut dibuat dalam konten yang lebih artistik dan interaktif sehingga hanya dengan melihat anak-anak sudah bisa memahami pesan yang disampaikan.

\section{METODE}

\section{Analisis Masalah}

Tidak hanya masalah penyampaian pesan tentang pola hidup sehat saja tapi ada banyak masalah yang dihadapi oleh mitra seperti:

1. Teknik penyampaian informasi pola hidup sehat pencegahan penyebaran virus covid 19 masih monoton 
Yuli Astuti, dkk. Animasi 2 Dimensi Sebagai Infografis Pencegahan Virus Covid 19...

dengan teks dan share berita dari media sosial

2. Kemampuam untuk mendesain poster yang digunakan untuk menyampaikan informasi atau pengumuman ke wali murid masih minim

3. Dalam pembelajaran centra, anakanak diperlihatkan vidio sesuai tema pembelajaran untuk mengasah motorik anak

\section{Penentuan Solusi}

Dari permasalahkan yang ada, ditawarkan beberapa solusi beserta keluaranya seperti:

1. Penyampaian informasi dirubah ke dalam bentuk poster infografis milik mitra

2. Pendampingan secara khusus ke wali kelas untuk transfer knowledge

3. Pembuatan video animasi 2D sebagai infografis pencegahan virus covid 19 milik mitra

\section{Pemilihan Solusi}

Dari tiga penentuan solusi yang ada, penulis memilih solusi pembuatan video animasi 2D infografis pencegahan virus covid 19 milik mitra sebagai informasi pada PAUD Terpadu Allifa.

\section{HASIL DAN PEMBAHASAN}

\section{Perancangan (Storyboard)}

Sebelum pembuatan video animasi 2 Dimensi infografis ini akan dibuat perancanngannya menggunakan storyboard untuk memudahkan pengecekan jika ada kesalahan alur dan sebagai panduan untuk mempermudah pada saat pembuatannya, storyboard tersebut terdapat pada gambar 1 .

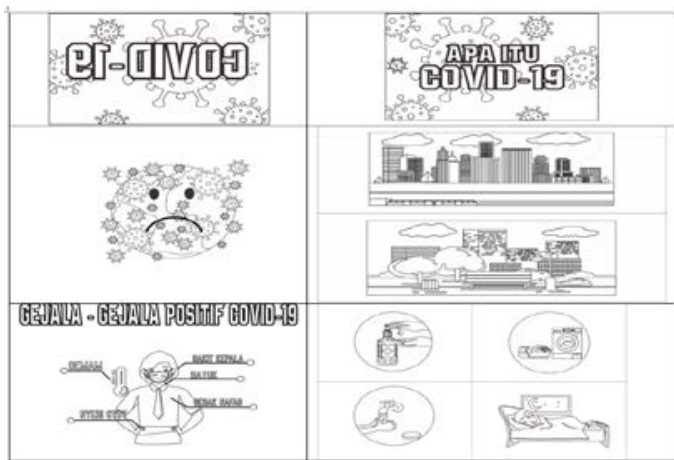

Gambar 1. Storyboard Video Animasi 2D sebagai Infografis

\section{Produksi Pembuatan Karakter}

Pada proses produksi pembuatan video prosedur yang dilakukan adalah membuat karakter dan backgroud dengan menggunakan Corel Draw X7, seperti pada gambar 2 .

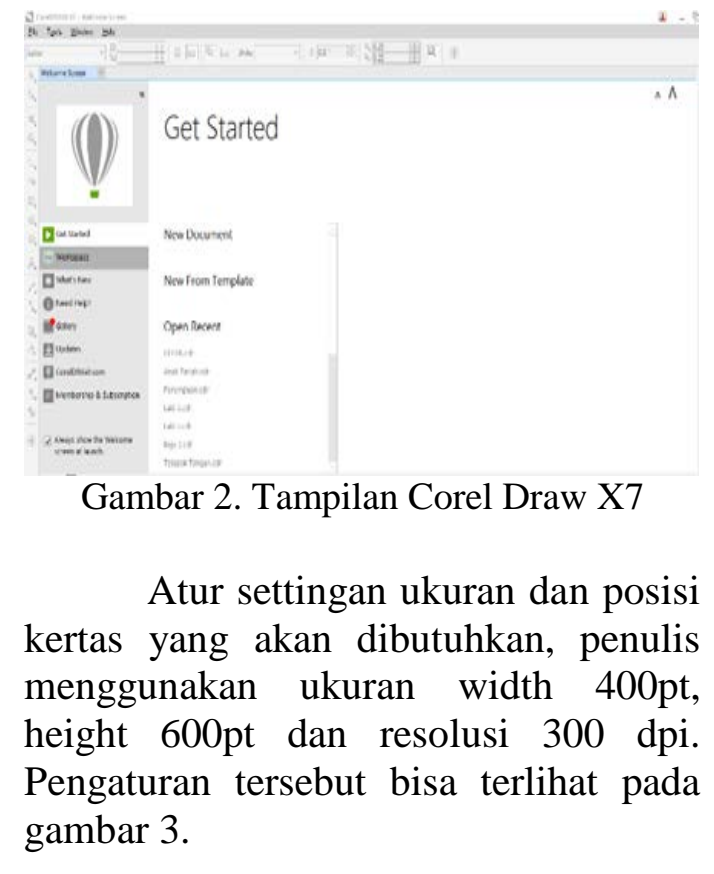




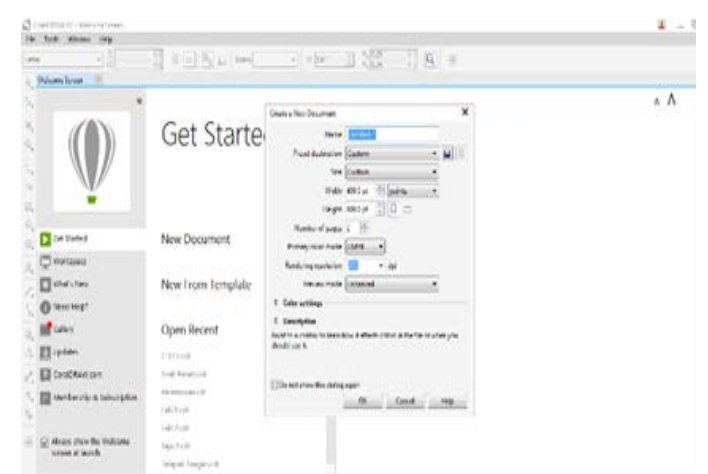

Gambar 3. Pengaturan Posisi dan Resolusi

1. Menggambar atay menyeket objek dengan tools B-SPLINE TOOL, seperti terlihat pada gambar 4.

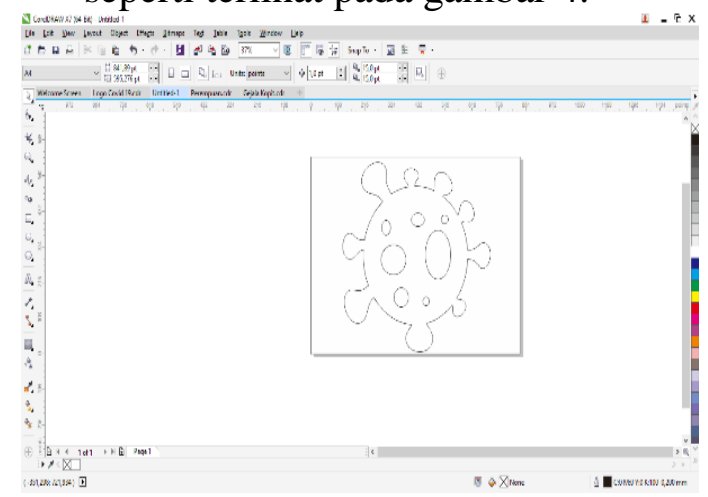

Gambar 4. Membuat Desain dengan BSpline Tools

2. Kemudian gambar dikasih pallet warna yang tersedia dan warnai sesuai keinginan, seperti terlihat paga gambar 5 .

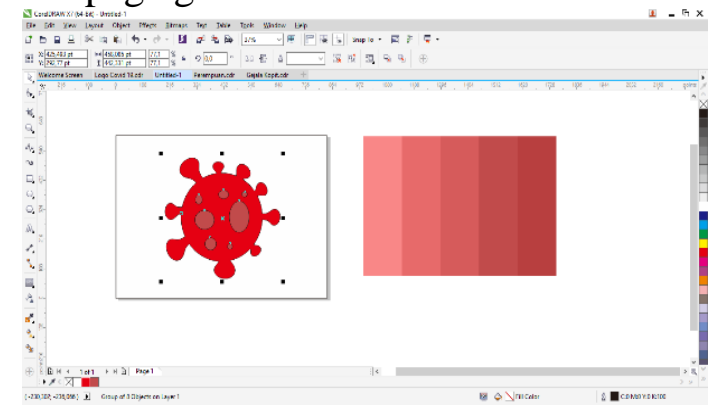

Gambar 5. Pemberian Pallet Warna

3. Apabila proses menggambar dan mewarnai sudah selesai langkah, langkah berikutnya adalah mengexport gambar dengan cara CTRL+E lalu tekan export, seperti pada gambar 6 .

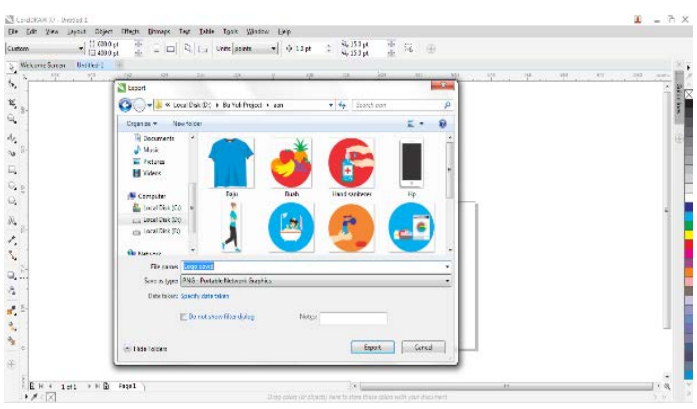

Gambar 6. Mengeksport Gambar

4. Kemudian, apabila muncul seperti ini tekan $\mathrm{OK}$

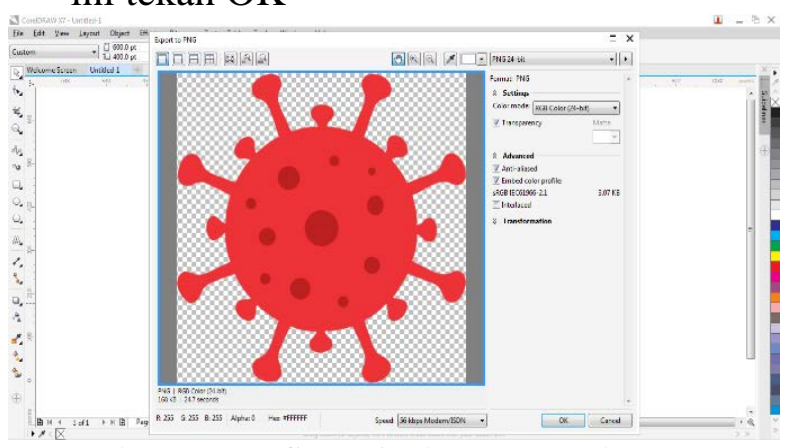

Gambar 7. Konfirmasi Eksport Gambar

Dari proses produksi yang telah dilakukan, terdapat dua jenis gambar yaitu cdr dan png.

\section{Naskah}

Penulisan naskah dibutuhkan untuk penyampaian pesan yang baik, penyesuaian intonasi yang sesuai dengan pengucapan dan teknik penulisan visualisasi yang pas dan menarik agar saat di perdengarkan. Naskah pada video ini terdapat pada Tabel 1.

Tabel 1. Naskah Video Infografis

\begin{tabular}{ll} 
Scene & \multicolumn{1}{c}{ Naskah } \\
\hline 1 & $\begin{array}{l}\text { Halo, adik-adik PAUD Allifa Terpadu } \\
\text { Pokoh Wedomartani apa kabar kalian } \\
\text { semuanya? Dimasa sekarang ini, siapa } \\
\text { yang tidak tau tentang virus covid 19? }\end{array}$ \\
2 & $\begin{array}{l}\text { Apa itu covid 19? Covid 19 atau biasa } \\
\text { disebut dengan corona virus }\end{array}$ \\
& Virus corona merupakan sekelompok \\
& virus yang menginfeksi saluran \\
& pernafasan pada manusia, mulai dari \\
batuk, pilek hingga sakit yang lebih \\
serius
\end{tabular}


Yuli Astuti, dkk. Animasi 2 Dimensi Sebagai Infografis Pencegahan Virus Covid 19...

4 Virus corona dapat dijumpai di tempat-tempat berikut ini seperti , transportasi dan tempat umum, contohnya rumah sakit, supermarket, tempat wisata, jalan raya dan lain-lain.

5 Berikut adalah gejala-gejala positif covid 19 seperti sakit kepala, batuk, sesak nafas, demam tinggi dan nyeri otot.

$6 \quad$ Jadi, adik-adik semuanya jangan lupa untuk selalu mandi 2 kali sehari, mencuci pakaian saat habis digunakan, rajin mencuci tangan dengan sabun, selalu membawa handsanitizer, rajin berolahraga, selalu mengkonsumsi buah-buahan dan olahan sayur, tidur yang cukup, gunakan masker saat keluar rumah dan selalu jaga jarak. Pesan-pesan yang disampaikan tadi sangat penting untuk kita lakukan dalam kehidupan sehari-hari, jangan lupa selalu mentaati protocol Kesehatan dimanapun berada dan semakin siap untuk era new normal. sangat penting untuk kita lakukan dalam kehidupan sehari-hari, jangan lupa selalu mentaati protocol Kesehatan dimanapun berada dan semakin siap untuk era new normal.

\section{Recording}

Prosedur terakhir dalam proses produksi adalah Recording. Pada tahapan ini narator yang telah melakukan latihan baik pelafalan, pengucapan dan penyampaian pesan akan langsung melakukan rekaman. Daftar track record yang telah dilakukan narrator terdapat pada Gambar10.

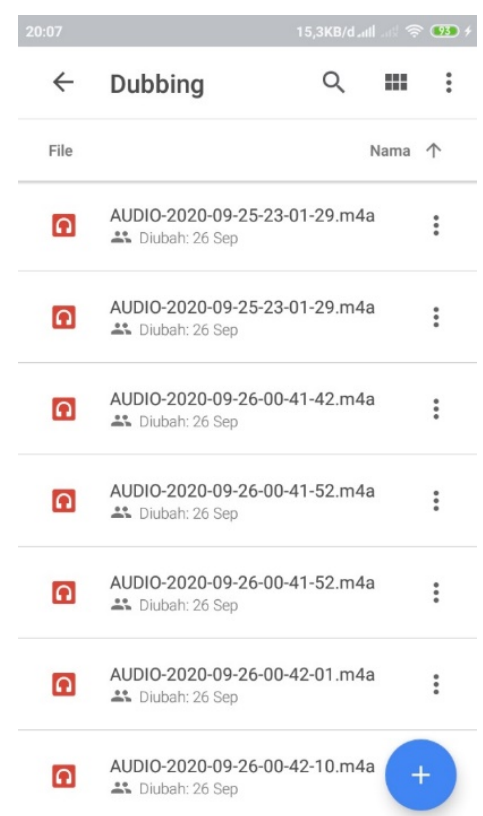

Gambar 8. Daftar track record

\section{Pasca Produksi \\ Compositing}

Compositing dilakukan untuk membuat animasi 2D motion graphic dan memberi special effect menggunakan software Adobe After Effect CC 2017. Berikut adalah tahapan compositingnya:

1. Buka software Adobe After Effect CC 2017

2. Import project yang telah di buat, setelah itu testing kembali video animasi yang pernah dibuat dengan cara render preview.

3. Kemudian render video animasi yang dibuat, seperti pada gambar 8 .

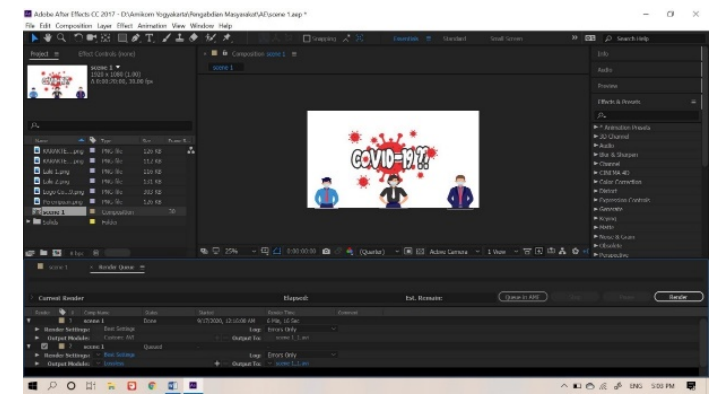

Gambar 9. Import dan Render

4. Dan pilih menu di render setting 
quality video menjadi Best seperti pada gambar 9 .

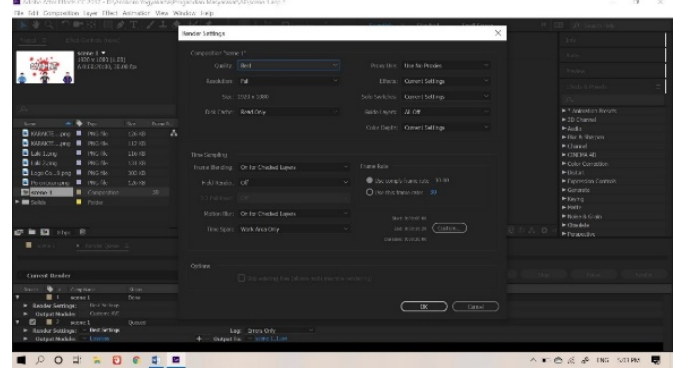

Gambar 10. Pengaturan Kualitas Render

5. Setelah itu pilih folder untuk menyimpan project yang sudah dibuat

6. Klik render dan tunggu sampai selesai

\section{Editing}

Editing video dilakukan untuk menggabungkan hasil video yang sudah dibuat sebelumnya pada Adobe Premier Pro CS6. Langkah untuk editingnya sebagai berikut:

1. Buka software Adobe Premier Pro CS6, maka akan muncul tampilan Startup, kemudian pilih project yang pernah dibuat.

2. Testing kembali video yang pernah dibuat

3. Render ulang pada pembuatan animasi 2D ini menggunakan software Adobe Premier Pro CS6

4. Klik menu file dan pilih Export Media. Kemudian, Format video yang awalnya AVI kita rubah menjadi H.264 (.mp4).

5. Kemudian, Format video yang awalnya AVI kita rubah menjadi H.264 (.mp4) dan setelah memilih format video dilanjutkan dengan memilih folder penyimpanan sesuai project yang sebelumnya sudah disimpan.

6. Klik Export kemudian tunggu sampai proses render selesai.

\section{Pengujian}

Setelah pembuatan video maka selanjutnya melakikan pengujian, pengujian pada video infografis ini selain mencocokkan dengan storyboard juda dilakukan dengan pengujian ke pihak mitra untuk meminta masukan atau saran apakah hasil video sudah sesuai dengan yang diharapkan oleh mitra, dan sudah dilakukan beberapa kali revisi sesuai dengan kebutuhan mitra.

\section{SIMPULAN}

Pada pengabdian masyarakat ini menghasilkan luaran berupa video animasi 2 dimensi yang memberikan informasi tentang pola hidup sehat untuk pencegahan penularan virus covid 19, dengan desain yang sudah disetujui oleh pihak mitra. Karena keterbatasan waktu pengerjaan, dalam pembuatan video ini masih ada kekurangan yaitu durasi waktu bisa diperpanjang agar bisa memuat banyak informasi lebih banyak.

\section{UCAPAN TERIMA KASIH}

Terima kasih banyak kami ucapkan ke Lembaga Pengabdian Masyarakat Universita Amikom Yogyakarta yang telah memberikan dukungan secara finansial dan terima kasih juga kami ucapkan kepada Mitra kami PAUD Terpadu Allifa Pokoh Wedomartani sehingga kegiatan pengabdian ini berjalan dengan lancer.

\section{DAFTAR PUSTAKA}

Anonim, 'Pelaksanaan Kebijakan Pendidikan Dalam Masa Darurat Penyebaran CORONA Virus Disease (COVID- 19)' (Menteri Pendidikan dan Kebudayaan Republik 
Yuli Astuti, dkk. Animasi 2 Dimensi Sebagai Infografis Pencegahan Virus Covid 19...

Indonesia, 2020)

Bustanil, M., Asrowi, \& Ardianto, D.

T., 'Pengembangan Media

Pembelajaran Interaktif

Berbasis Video Tutorial Di

Sekolah Menengah Kejuruan',

JTP - Jurnal Teknologi

Pendidikan, 21.2 (2019), 119-

34

<https://doi.org/https://doi.org/

10.21009/JTP.V21I2.11568>

Filasofa;, M. Fadlillah; Lilif Muallifatul Khorida;, Wantini;, Eliyyil Akbar;, and Syifa Fauziah, Edutainment Pendidikan Anak Usia Dini Menciptakan Pembelajaran Menarik, Kreatif Dan Menyenangkan, 1st edn (Jakarta: Kencana Prenadamedia Group, 2014)

Yunanto, A. A., Herumurti, D., Rochimah, S., \& Kuswardayan, I, 'English Education Game Using NonPlayer Character Based on Natural Language Processing', Procedia Computer Science, 161 (2019), 502-8 <https://doi.org/https://doi.org/ 10.1016/j.procs.2019.11.158> 